\section{The Effect of Bank Capital Buffer on Bank Risk and Net Interest Margin: Evidence from the US}

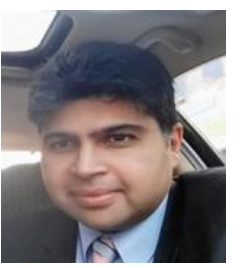

\author{
iD Faisal Abbas ${ }^{1}$ \\ (iD) Shazaib Butt ${ }^{2}$ (f) \\ (iD) Omar Masood ${ }^{3}$ \\ iD Kiran Javaria ${ }^{4}$
}

\author{
The University of Lahore, Pakistan. \\ ${ }^{2}$ Email:faisalabbaspcc@gmail.com \\ ${ }^{2}$ Royal Docks School of Business and Law, University of East London, England. \\ `Email:s.butt@uel.ac.uk \\ ${ }^{8,4}$ School of Accountancy and Finance, University of Lahore, Islamabad, Pakistan. \\ ${ }^{3}$ Email:masood_omar@hotmail.com \\ EEmail:kiranmaryam23@gmail.com
}

Global Journal of Social Sciences Studies

Vol. 5, No. 2, 72-87, 2019

e-ISSN: 2518-0614

(T) Check for updates $\begin{gathered}\text { check for } \\ \text { updates }\end{gathered}$

\title{
ABSTRACT
}

This study used a balanced panel data set of USA well, adequately, under, significantly under and critically undercapitalized large commercial banks in pre, during and post-crisis period to investigate the effect of the capital buffer, tier one capital buffer and common equity buffer on risk and net interest margin. The Generalized Method of Moment (GMM) two-step estimation was applied. The conclusions showed that the capital buffer, common equity buffer, tier one capital buffer and total risk are negatively correlated. The findings of period dummies and subgroups dummies showed that capital buffer is influencing the total risk and net interest margin differently in pre, during and postcrisis. The results indicated that the interest margin is lower in pre-crisis and during crisis period than in the post-crisis period, which signifies the impact of capital restrictions imposed by regulators in Basel-III. The outcomes showed that the influence of capital buffer on the net interest margin is not similar in all the subgroups. In addition, the results indicated that there is a positive relationship between bank risk and net interest margin. The findings also displayed that the lagged risk and current risk are positively related.

Keywords: Capital buffer, Tier I capital buffer, Total risk, Net interest margin.

DOI: $10.20448 / 807.5 .2 .72 .87$

Citation | Faisal Abbas; Shazaib Butt; Omar Masood; Kiran Javaria (2019). The Effect of Bank Capital Buffer on Bank Risk and Net Interest Margin: Evidence from the US. Global Journal of Social Sciences Studies, 5(2): 72-87.

Copyright: This work is licensed under a Creative Commons Attribution 3.0 License

Funding: This study received no specific financial support.

Competing Interests: The authors declare that they have no competing interests.

History: Received: 25 January 2019/ Revised: 4 March 2019/ Accepted: 10 April 2019/ Published: 21 May 2019 Publisher: Online Science Publishing 


\section{INTRODUCTION}

The world financial system has undergone a significant transformation during the last three decades. The globalization has increased competition in banking sectors of the developed, developing and emerging economies around the world. This globalization and technological transformation have encouraged financial institutions to develop new innovative financial products to fulfill the current requirements. Since Basel I 1988, the regulators have been trying to provide a universal model to manage the bank capital. Thus, Basel II was presented in 2004. However, the financial crisis 2007-2008 showed that the higher ratio of capital, imposed by Basel II, was inadequate to avoid banks failure. These inadequacies of Basel II motivated the regulators to develop new and more appropriate guidelines to fill this gap in the banking system. The Basel Committee on Banking and Supervision (BCBS) provided new guidelines for banking supervision under the title "Basel-III" in 2010, which provides new definitions of bank capital and bank liquidity as core instruments to manage.

The last financial crisis was an insolvency risk crisis, not a liquidity crisis (Thakor, 2018). In fact, there is a gap in the present literature on the banking sector as the effect of the changes in a bank capital on the risk and performance of banks addition has not been investigated entirely in previous research (Molyneux, 2018) Therefore, the present study is aimed to explore the effect of bank capital buffer on bank risk and net interest margin of well, adequately, significantly under, and critically undercapitalized banks in the USA for the pre, during and post-crisis period.

Theoretically, regulators want to strengthen the financial institutions; therefore, they impose conditions on banks to maintain a particular amount of excess capital as a buffer to absorb losses. Although the increase in the capital buffer either through issuing of new equity or by retained earnings diminishes the chances of the insolvency of banks, it increases their cost. However, the finance theory and banking literature indicate that issuing of new equity in the capital market is too costly during the bad economic period because of the agency theory hypothesis and information asymmetries (Jensen and Meckling, 1976; Myers, 1984). On one hand, the higher capital provides self-insurance to the bank and boosts the confidence of depositors about the soundness of their banks. On the other hand, the lower risk of banks provides the incentive to pay lower rates to depositors. The capital buffer theory suggests that the excessive increase in capital than required decreases the risk of the bank (Jokipii and Milne, 2011). The theory suggests that capital buffer may increase the performance of banks due to reducing the rate of lending, which increases the demand for loans. In this case, banks have the incentive to charge a higher rate of interest on limited loans. In addition, by monitoring and screening the borrowers to reduce the default risk, the profitability of banks increases in the short run, ceteris paribus. The second argument for the positive impact of bank capital ratio is the cost of capital. If the banks are facing a higher cost of deposits due to their riskiness, the contribution of capital will lead to a decrease in the risk of banks as well as the cost of funding as the profitability will increase. The literature indicates that banks normally maintain capital buffer through their profitability (Shim, 2013). The positive relationship between the capital buffer and profitability is in line with the pecking order theory (Myers, 1984).

The current study is different from previous research due to the following reasons: Firstly, this study includes a period of seventeen years, which has not been investigated yet. Secondly, the study uses the three proxies of the capital buffer, tier one capital buffer, and common equity buffer, which has not been used in previous studies. Thirdly, this study examines the influence of capital buffer on risk using pre, during and postcrisis for comparison purposes which are also not found in previously reported literature on banking. Fourthly, the study uses net interest margin for bank performance and investigates the effect of capital buffer on net interest margin in pre, during, and post-crisis for well, adequately, under, significantly under, and critically under-capitalized large commercial banks of the USA. 
The motivation behind present study is it explores the effect of bank capital buffer on risk and performance in pre, during, and post-crisis period of well, adequately, under, significantly under, and critically undercapitalized large commercial banks of the US. The study focuses on investigating the influence of capital buffer on the net interest margin of large commercial banks, which is lacking in banking literature on the postcrisis period. The study uses three proxies of buffer namely (I) capital buffer (II) tier one capital buffer, and (III) common equity buffer because the evidence on the influence of tier one capital buffer and common equity buffer ratios are not found in the banking literature. Significantly, the study covers an extended time between 2002 and 2018. Unlike past research, the study used a two-step dynamic panel inception examination threshold for analysis. To the best of the researcher's information, this is the first study providing comparative evidence of large commercial banks about the effect of three bank capital buffer ratios on bank risk and bank net interest margin using the data for pre, during and post-crisis of well, adequately, under, significantly under and critically undercapitalized banks.

\section{LITERATURE REVIEW}

According to Basel III, some restrictions are imposed on banks to maintain a specific amount of capital buffer during good economic situations. Regulators provide the guidelines to maintain a $2.5 \%$ conservative capital buffer in order to decrease failure in bad economic situations. Krug et al. (2015) argue in their study that banks maintain a capital buffer in the credit growth period. Buser et al. (1981) demonstrate that banks maintain a high amount of a buffer capital to evade surcharge imposed by the policymakers regarding the minimum amount of capital. Ayuso et al. (2004) argue that a capital buffer is a tool for banks to mitigate excessive risk, which means when a bank maintains a greater amount of capital buffer against an increase in their risk, it remains able to survive in a difficult period. Guidaraa et al. (2010) used Return on Assets (ROA) as a performance indicator and concluded that capital buffer has a positive impact on profitability. They also opine that capital buffer variation is more pronounced in the crisis period than in an economic boom. Guidaraa et al. (2010) indicated that capital buffer increases the risk exposure of banks. Tabak et al. (2013) used Return on Assets (ROA) and Return on Equity (ROE) for bank performance and found a positive relationship between the holding of capital buffer and profitability of banks. They argue that holding a higher capital buffer represents stability in the market. Bagntasarian and Mamatzakis (2019) conducted a study using Return on Equity (ROE), Return ON Assets (ROA) and Net Interest Income (NIM) as performance measures and found a positive relationship between capital buffer and profitability. They also demonstrated that a high capital buffer reflects stability in banks.

In addition, this study is filling a gap in the literature. In fact, several studies provided contradictory results concerning the nature of the relationship between holding great capital and profitability of banks (such as Alfon et al. (2004); Guidara et al. (2013); Nier and Baumann (2006); Jokipii and Milne (2008)). However, the contradictory findings of two major studies conducted by Berger (1995) and Jokipii and Milne (2008) on banking reflect the importance of further research investigating the relationship between performance and holding great capital. On one hand, Berger (1995) found a positive relationship between great capital and equity return in USA commercial banks. On the other hand, Jokipii and Milne (2008) demonstrated that there is a negative relationship between equity and profitability. Moreover, Flannery and Rangan (2008) found a positive relationship between capital buffer and bank performance, which is supported by other studies Nier and Baumann (2006); Shim (2013). The findings indicating the positive relationship between bank capital and profitability are supporting the pecking order theory of capital structure (Myers, 1984). Notably, most of the researchers used ROA and ROE to investigate the impact of capital buffer on bank performance. very limited 
studies, such as Bagntasarian and Mamatzakis (2019) investigated the impact of capital buffer on net interest margin. The purpose of the study is to investigate the effect of capital buffer on net interest margin to fill this gap for further decision making in the future.

Jokipii and Milne (2011) demonstrated in their seminal study on the adjustment of capital buffer and bank risk in the short run that there is a positive relationship between risk and capital buffer. They also argue that the relationship is varying and depending on the capitalization of banks. Guidara et al. (2013) explored the impact of bank capital buffer on bank risk in Canadian banks. They used two-step GMM estimators and concluded the nonexistence of relationship between banks risk exposure and capital buffer in Canadian banks. Shrieves and Dahl (1992) provided evidence on the relationship between risk and capital in the US banking industry covering the period between 1984 and 1986. They used risk-weighted assets as a risk measure and found a positive relationship between risk and bank level of capital, which aligns with the theory of managerial risk aversion hypothesis. Jacques and Nigro (1997) opine that there is a negative relationship between bank equity and bank risk exposure. They used tier one plus tier two capital as equity ratio and risk-weighted assets as a risk proxy. They concluded that an increase in equity of banks leads to a decrease in the risk of banks.

Altunbas et al. (2007) used European banks data for nine years ranging between 1992 and 2000. They explored the impact of capital on risk and concluded that there is a positive relationship between risk and capital level in case of saving and commercial banks. Aggarwal and Jacques (2001) investigated the relationship between risk and capital under the conditions of Prompt Corrective Action and concluded that an increase in capital ratio leads to a decrease in the credit risk of banks in the USA. However, they also used limited data of US commercial banks covering between 1993 and 1997. Rime (2001) investigated the relationship between bank capital and risk-taking by using data of the Swiss banking industry, and their findings supported the positive effect on capital, but it has an insignificant influence on risk. Mongid et al. (2012) opined that the impact of capital ratio on risk is negative which means an increase in the bank capital level leads to a decrease in bank risk. They use d ASEN banking industry and used six-year data between 2003 and 2008. They also found that the effect of risk on capital is insignificant.

\section{DATA AND ECONOMETRIC MODELS}

\subsection{Data and Sample Selection}

In this study, Federal Deposit Insurance Corporation institution directory is used to extract detailed financial information required for analysis as reported by FFIEC call/TFR report, which is updated by the corporation on a quarterly basis. The annual data for each financial institution is retrieved covering the period between 2002 and 2018. The sample of this study is balanced panel data including insured large commercial banks as reported by FDIC based on consolidated assets. There were 1806 banks in the list dated 31 December 2018 provided by FDIC. However, the selection of the sample for analysis was made based on certain criteria: I) a bank must have active status on reported date; 2) a bank must not have missing values for any variables more than two years in the whole time period; 3) banks must have total assets greater than $\$ 300$ million dated 31 December 2018. After filtering as per the criteria explained, 942 banks were selected.

\subsection{Definitions and Measurement of Variables}

Capital buffer contains three proxies: total risk-based capital buffer (capital buffer onward), which is measured as actual total risk-based capital ratio minus $8 \%$, the second actual ratio is of tier one risk-based capital (tier I capital buffer onward) less $6 \%$, and the third ratio is of common tier one equity capital ratio (common equity buffer onward) 4.5\%. Most of the studies used total capital buffer ratio like Guidara et al. 
(2013); Jokipii and Milne (2008); Jokipii and Milne (2011); Shim (2013) and Bagntasarian and Mamatzakis (2019). Bank risk is measured as the ratio of total risk-weighted assets to total assets, which is similar to Bagntasarian and Mamatzakis (2019). Net interest margin is measured as interest income less interest expense scaled by total assets, which is similar to Robin et al. (2018); Bitar et al. (2018) and Batten and Vo (2019). Liquidity is measured as liquid assets to total assets of banks. Liquidity can influence bank net interest margin positively and bank risk inversely (Shim, 2013).

Loan ratio is measured as total loans to total assets. The excessive loans ratio may adversely affect the bank interest margin and may positively relate to risk. Operating efficiency is measured by non-interest expenses to total assets (Bitar et al., 2018). The operating efficiency can influence net interest margin and bank risk positively and negatively. The greater operating efficiency leads to a decrease in bank risk and an increase in bank performance. Income diversification is currently a focused indicator both in interest margin and risktaking. This indicator has an economic value for banks to reduce risk and increase interest margin. The income diversification is measured as the non-interest income to gross revenue (Shim, 2013). Bank size is measured by taking a natural log of bank total assets. The first theory suggests that banks' large size leads to a decrease in cost and an increase in profitability due to economies of scales. The other argument suggests that large banks may not remain able to reduce their cost, which leads to lower profits (Robin et al., 2018); (Shim, 2013). The theory also provides an economic justification for risk and bank size relationship. This argument indicates that larger banks take higher risks due to the too-big-too-fail theory (Shim, 2013).

\subsection{Empirical Econometric Model}

The basic purpose of this study is to investigate the effect of different proxies of capital buffer on bank risk and net interest margin. This relationship can be written in the static form in the following equations:

$$
\begin{gathered}
\text { Bank risk }_{i, t}=\beta_{1} \text { Capital Buffer }_{\mathrm{i}, \mathrm{t}}+\beta_{2} \text { NIM }_{\mathrm{i}, \mathrm{t}}+\beta_{3} \text { Liquditiy }_{\mathrm{i}, \mathrm{t}}+\beta_{4} \text { Loan Ratio }_{\mathrm{i}, \mathrm{t}}+\beta_{5} \text { Operting Efficiecny }_{\mathrm{i}, \mathrm{t}}+ \\
\beta_{6} \text { Income Diversification }_{\mathrm{i}, \mathrm{t}}+\beta_{7} \text { Size }_{\mathrm{i}, \mathrm{t}}+\varepsilon
\end{gathered}
$$

$$
\begin{gathered}
N I M_{i, t}=\beta_{1} \text { Capital Buffer }_{\mathrm{i}, \mathrm{t}}+\beta_{2} \text { Bank Risk }_{\mathrm{i}, \mathrm{t}}+\beta_{3} \text { Liquditiy }_{\mathrm{i}, \mathrm{t}}+\beta_{4} \text { Loan Ratio }_{\mathrm{i}, \mathrm{t}}+\beta_{5} \text { Operting }_{\text {Efficiecny }} \text { (i,t }+ \\
\beta_{6} \text { Income Diversification }_{\mathrm{i}, \mathrm{t}}+\beta_{7} \text { Size }_{\mathrm{i}, \mathrm{t}}+\varepsilon
\end{gathered}
$$

The results of the static Equation $1 \& 2$ cannot consider the problems of autocorrelation, heteroscedasticity, and simultaneity of data, which lead to biased results. To avoid the problems of endogeneity (correlation of explanatory variables with error terms) and dependence of lagged information of endogenous variables, this study uses a dynamic panel methodology to estimate the unbiased and consistent estimators Blundell and Bond (2000); Arellano and Bover (1995). The dynamic system methodology makes the available flexible variance and covariance system under the desired conditions. There are different simulations to use dynamic panel data models under the condition of one-step and two-step estimators such as difference panel estimators and system panel estimator. The two-step linear GMM estimator is used because it is considered more efficient than the estimator of one step linear GMM approach (Windmeijer, 2005). The Two-step dynamic panel data approach was used by Lee and Hsieh (2013) to investigate the relationship of bank capital, profitability, and risk. It was also used by Altunbas et al. (2007) to investigate the association of bank capital, efficiency, and risk. Similarly, Casu and Girardone (2006) used the twostep dynamic panel data approach to inspect the relationship between capital and profitability. The equation $3 \& 4$ reprsenet the standard form of the dynamic model can be written as follows:

$$
\begin{gathered}
\text { Bank risk }_{i, t}=\beta_{1} \text { Bank risk }_{\mathrm{i}, \mathrm{t}-1}+\beta_{2} \text { Capital Buffer }_{\mathrm{i}, \mathrm{t}}+\beta_{3} \text { NIM }_{\mathrm{i}, \mathrm{t}}+\beta_{4} \text { Liquditiy }_{\mathrm{i}, \mathrm{t}}+\beta_{5} \text { Loan Ratio }_{\mathrm{i}, \mathrm{t}}+ \\
\beta_{6} \text { Operting Efficiecny }_{\mathrm{i}, \mathrm{t}}+\beta_{7} \text { Income Diversification }_{\mathrm{i}, \mathrm{t}}+\beta_{8} \text { Size }_{\mathrm{i}, \mathrm{t}}+\varepsilon \\
\operatorname{NIM}_{i, \mathrm{t}}=
\end{gathered}
$$




$$
\begin{aligned}
& \beta_{1} \text { NIM }_{\mathrm{i}, \mathrm{t}-1}+\beta_{2} \text { Capital Buffer }_{\mathrm{i}, \mathrm{t}}+\beta_{3} \text { Bank Risk }_{\mathrm{i}, \mathrm{t}}+\beta_{4} \text { Liquditiy }_{\mathrm{i}, \mathrm{t}}+\beta_{5} \text { Loan Ratio }_{\mathrm{i}, \mathrm{t}}+ \\
& \beta_{6} \text { Operting Efficiecny } \\
& \mathrm{i}, \mathrm{t}
\end{aligned}
$$

The Equation $3 \& 4$ represent the dynamic form of models used in this study. Here " $\mathrm{t}$ " is defined as the bank period until the day data of the bank was obtained. $(\beta 1, \beta 2, \beta 3, \beta 4, \beta 5, \beta 5, \beta 7, \beta 8)$ are the structural parameters of the equation, "i" is the bank where " $\varepsilon$ " is symbolic of the error term. The coefficient in reaction to a variation in the variable attains the short-term influence on bank risk and net interest margin in the above model of econometrics.

This study investigates the effect of capital buffer on bank risk and net interest margin for the pre, during and post-crisis period. The model Equation $5 \& 6$ were used with the inclusion of dummies variable for the crisis period as follows:

$$
\begin{gathered}
\text { Bank risk }_{i, t}= \\
\beta_{1} \text { Bank risk }_{\mathrm{i}, \mathrm{t}-1}+\beta_{2} \text { Capital Buffer }_{\mathrm{i}, \mathrm{t}}+\beta_{3} \text { NIM }_{\mathrm{i}, \mathrm{t}}+ \\
\beta_{4} \text { Liquditiy }_{\mathrm{i}, \mathrm{t}}+
\end{gathered}
$$

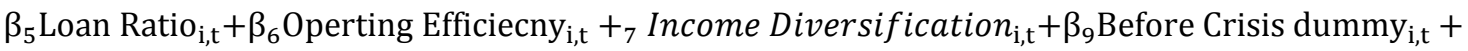
$+\beta_{10}$ After Crisis dummy $\mathrm{i}_{\mathrm{i}, \mathrm{t}}+\beta_{8}$ Size $_{\mathrm{i}, \mathrm{t}}+\varepsilon$

$$
N I M_{i, t}=
$$

$$
\beta_{1} \text { NIM }_{\mathrm{i}, \mathrm{t}-1}+\beta_{2} \text { Capital Buffer } \mathrm{i}_{\mathrm{t}, \mathrm{t}}+\beta_{3} \text { Bank Risk }_{\mathrm{i}, \mathrm{t}}+\beta_{4} \text { Liquditiy }_{\mathrm{i}, \mathrm{t}}+\beta_{5} \text { Loan Ratio }_{\mathrm{i}, \mathrm{t}}+
$$

$\beta_{6}$ Operting Efficiecny $\mathrm{i}_{\mathrm{i}, \mathrm{t}}+$

$$
\beta_{7} \text { Income Diversification }_{\mathrm{i}, \mathrm{t}}+\beta_{9} \text { Before Crisis dummy }_{\mathrm{i}, \mathrm{t}}+\beta_{10} \text { After Crisis dummy }_{\mathrm{i}, \mathrm{t}}+\beta_{8} \text { Size }_{\mathrm{i}, \mathrm{t}}+\varepsilon
$$

This study also examines the influence of bank capital buffer on the bank risk and the net interest margin according to the bank capitalization as proposed by regulators. The banks are categorized into five subgroups for which dummies are used. The following equations are estimated to investigate how bank capital buffer influences the risk and the net interest margin of well, adequately, under, significantly under and critically undercapitalized banks in the USA. The Equations $7 \& 8$ are proposed to examine these effects:

$$
\begin{gathered}
\text { Bank risk }_{i, t}= \\
\beta_{1} \text { Bank risk }_{\mathrm{i}, \mathrm{t}-1}+\beta_{2} \text { Capital Buffer }_{\mathrm{i}, \mathrm{t}}+\beta_{3} \text { NIM }_{\mathrm{i}, \mathrm{t}}+
\end{gathered}
$$

$\beta_{4}$ Liquditiy $_{\mathrm{i}, \mathrm{t}}+\beta_{5}$ Loan Ratio $_{\mathrm{i}, \mathrm{t}}+\beta_{6}$ Operting Efficiecny $_{\mathrm{i}, \mathrm{t}}+{ }_{7}$ Income Diversification $_{\mathrm{i}, \mathrm{t}}+\beta_{9}$ Well Cap dummy $_{\mathrm{i}, \mathrm{t}}+$ $+\beta_{10}$ Adq Cap dummy $_{\mathrm{i}, \mathrm{t}}+\beta_{11}$ Under Cap dummy $_{\mathrm{i}, \mathrm{t}}+\beta_{12}$ SigUnder Cap dummy $_{\mathrm{i}, \mathrm{t}}+\beta_{8}$ Size $_{\mathrm{i}, \mathrm{t}}+\varepsilon$

$$
N I M_{i, t}=
$$

$$
\beta_{1} \text { NIM }_{\mathrm{i}, \mathrm{t}-1}+\beta_{2} \text { Capital Buffer }_{\mathrm{i}, \mathrm{t}}+\beta_{3} \text { Bank Risk }_{\mathrm{i}, \mathrm{t}}+\beta_{4} \text { Liquditiy }_{\mathrm{i}, \mathrm{t}}+\beta_{5} \text { Loan Ratio }_{\mathrm{i}, \mathrm{t}}+
$$

$\beta_{6}$ Operting Efficiecny $_{\mathrm{i}, \mathrm{t}}+\beta_{7}$ Income Diversification $_{\mathrm{i}, \mathrm{t}}+\beta_{9}$ Before Crisis dummy $_{\mathrm{i}, \mathrm{t}}+\beta_{9}$ Well Cap dummy $_{\mathrm{i}, \mathrm{t}}+$

$+\beta_{10}$ Adq Cap dummy $\mathrm{i}_{\mathrm{i}, \mathrm{t}}+\beta_{11}$ Under Cap dummy $_{\mathrm{i}, \mathrm{t}}+\beta_{12}$ SigUnder Cap dummy $_{\mathrm{i}, \mathrm{t}}+\beta_{8}$ Size $_{\mathrm{i}, \mathrm{t}}+\varepsilon$

\section{RESULTS AND DISCUSSIONS}

\subsection{Descriptive Analysis of Study}

Table 1 contains the information of proxies used in this study. The results show that the total risk and the net interest margin have average values of .723 and .033 respectively. The average values of the capital buffer, tier one capital buffer and common equity buffer is $0.059,0.066$ and 0.082 respectively. The mean value of liquidity 0.048 , loan ratio 0.714 , income diversification 0.463 , operating efficiency 0.027 and size is 13.554 . 
Table-1. Descriptive Statistics.

\begin{tabular}{lccccc}
\hline Tariable & Obs & Mean & Std.Dev. & Min & Max \\
\hline Total Risk & 14130 & 0.723 & 0.11 & 0.494 & 0.901 \\
Net Interest Margin & 14130 & 0.033 & 0.007 & 0.017 & 0.046 \\
Capital Buffer & 14130 & 0.059 & 0.021 & 0.033 & 0.092 \\
\hline Tier I Capital Buffer & 14130 & 0.066 & 0.019 & 0.043 & 0.095 \\
Common Equity Buffer & 14130 & 0.082 & 0.025 & 0.053 & 0.123 \\
Liquidity Ratio & 14130 & 0.048 & 0.027 & 0.021 & 0.095 \\
Loan Ratio & 14130 & 0.714 & 0.148 & 0.431 & 0.974 \\
\hline Income Diversification & 14130 & 0.463 & 0.098 & 0.262 & 0.593 \\
Operating Efficiency & 14130 & 0.027 & 0.009 & 0.012 & 0.046 \\
Bank SIZE & 14130 & 13.554 & 0.95 & 12.259 & 15.368 \\
\hline Source: Authors Calculations by using Stata 15 & & & & &
\end{tabular}

\subsection{Correlation Analysis}

Table 2 presents the findings of correlation among variables undertaken in this study. The correlation between the total risk and the net interest margin is positive whereas the correlation of total bank capital buffer, tier one capital buffer and common equity capital buffer are negative. The correlation between liquidity risks is negative whereas loans ratio and risk are positively correlated. The results also show that the correlations among total risk-based capital buffer, tier one risk based capital buffer and common equity tier one capital buffer are positive. There is no higher correlation among explanatory variables, which indicates that there is no problem with severing multicollinearity.

Table-2. Matrix of correlations.

\begin{tabular}{|c|c|c|c|c|c|c|c|c|c|c|}
\hline Variables & -1 & -2 & -3 & -4 & -5 & -6 & -7 & -8 & -9 & -10 \\
\hline Total Risk & 1 & & & & & & & & & \\
\hline Net Interest Margin & 0.222 & 1 & & & & & & & & \\
\hline Buffer Capital & -0.512 & -0.05 & 1 & & & & & & & \\
\hline Buffer Tier I Capital & -0.514 & -0.061 & 0.982 & 1 & & & & & & \\
\hline Buffer Com. Equity & -0.553 & -0.05 & 0.926 & 0.928 & 1 & & & & & \\
\hline Liquidity Ratio & -0.143 & -0.043 & 0.191 & 0.185 & 0.186 & 1 & & & & \\
\hline Loans Ratio & 0.664 & 0.184 & -0.448 & -0.44 & -0.468 & -0.16 & 1 & & & \\
\hline Income Diversification & -0.002 & 0.052 & 0.089 & 0.087 & 0.055 & 0.034 & -0.079 & 1 & & \\
\hline Operating Efficiency & 0.029 & 0.202 & -0.007 & -0.021 & -0.022 & 0.056 & -0.024 & 0.092 & 1 & \\
\hline Bank Size & 0.1 & -0.22 & -0.105 & -0.126 & -0.16 & -0.053 & -0.042 & 0.312 & -0.023 & 1 \\
\hline
\end{tabular}

\subsection{Regression Analysis/Generalized Method of Moment (GMM) of variables \\ 4.3.1. Impact of Capital Buffer on Total Risk of Banks}

Table 3 contains the results of how capital buffer influences the bank risk of well, adequately, under, significantly under and critically undercapitalized banks overall, pre, during and post-crisis of commercial banks. The results indicate that the lagged risk coefficient is positive and significant at $1 \%$ level of significance in the short run, other factors remain unchanged. The positive impact indicates that the previous risk is also contributing to the total risk of the current period. The findings show that capital buffer and bank risk are negatively correlated. The findings are similar to Saadaoui (2014) which indicates that an increase in capital buffer leads to a decrease in risk of commercial banks in the short run, ceteris paribus. Jokipii and Milne (2008); Ayuso et al. (2004) and Guidara et al. (2013) also concluded a negative relationship between risk and capital but during recession time. The coefficient shows that a one percent increase in capital buffer leads to a decrease of 0.541 percent in bank risk in the short run, other factors held constant. In economics, the findings are favoring the recommendations of regulators to maintain a conservative ratio of the capital buffer in order to reduce the riskiness. The findings of period dummies show that capital buffer is influencing the total risk differently pre, 
during and post-crisis. The coefficient shows that a one percent increase in capital buffer causes a decrease of $0.507 \%$ of the total risk in post-crisis whereas the $0.5912 \%$ in the pre-crisis period.

Table-3. Impact of capital buffer on total risk of banks.

\begin{tabular}{|c|c|c|c|}
\hline VARIABLES & Total Risk & Total Risk & Total Risk \\
\hline \multirow[t]{2}{*}{ Lagged. Risk } & $0.216 * * *$ & $0.227 * * *$ & $0.203^{*} * *$ \\
\hline & -0.0226 & -0.0241 & -0.0226 \\
\hline \multirow[t]{2}{*}{ Capital Buffer } & $-0.541 * * * *$ & $-0.507 * * *$ & $-0.568 * * *$ \\
\hline & -0.0687 & -0.067 & -0.0952 \\
\hline \multirow[t]{2}{*}{ Well Capitalized Dummy } & & & $0.429^{*} *$ \\
\hline & & & -0.217 \\
\hline \multirow[t]{2}{*}{ Adequately Capitalized Dummy } & & & -0.248 \\
\hline & & & -0.264 \\
\hline \multirow[t]{2}{*}{ Significantly Under-Capitalized Dummy } & & & -0.14 \\
\hline & & & -0.124 \\
\hline \multirow[t]{2}{*}{ Critically Under Capitalized Dummy } & & & -0.518 \\
\hline & & & -0.53 \\
\hline \multirow[t]{2}{*}{ Net Interest Margin } & $0.234 * * *$ & $0.226^{* * * *}$ & $0.232 * * *$ \\
\hline & -0.0652 & -0.0646 & -0.0658 \\
\hline \multirow[t]{2}{*}{ Liquidity Ratio } & $-0.278 * * *$ & $-0.287^{* * * *}$ & $-0.270 * * *$ \\
\hline & -0.0258 & -0.0254 & -0.0257 \\
\hline \multirow[t]{2}{*}{ Bank Size } & $0.0120^{* * * *}$ & $0.00616^{*}$ & $0.0130 * * *$ \\
\hline & -0.00271 & -0.00329 & -0.00271 \\
\hline \multirow[t]{2}{*}{ Income Diversification } & $0.0402^{* * * *}$ & $0.0431 * * *$ & $0.0431 * * *$ \\
\hline & -0.00922 & -0.00934 & -0.00929 \\
\hline \multirow[t]{2}{*}{ Operating Efficiency } & 0.0891 & 0.0725 & 0.088 \\
\hline & -0.0674 & -0.0673 & -0.0677 \\
\hline \multirow[t]{2}{*}{ Loan Ratio } & $0.690 * * *$ & $0.689^{* * * *}$ & $0.687 * * *$ \\
\hline & -0.0186 & -0.0185 & -0.0187 \\
\hline \multirow[t]{2}{*}{ Before Crisis Dummy } & & $-0.0842^{* *}$ & \\
\hline & & -0.0364 & \\
\hline \multirow[t]{2}{*}{ During Crisis Dummy } & & -0.0289 & \\
\hline & & -0.0298 & \\
\hline \multirow[t]{2}{*}{ Constant } & -0.038 & 0.0326 & -0.0408 \\
\hline & -0.037 & -0.043 & -0.0375 \\
\hline Observations & 14,130 & 14,130 & 14,130 \\
\hline Number of ids & 942 & 942 & 942 \\
\hline
\end{tabular}

The banks are divided into five subgroups to test whether the influence is similar or different for well, adequately, under, significantly under and critically undercapitalized banks. The results of dummies conclude that the effect of capital buffer on risk is not similar for well, adequately, under, significantly under and critically undercapitalized banks. The coefficient of well-capitalized banks dummy is significant and positive, but the net effect is negative (Saadaoui, 2014). This means that capital buffer reduces risk but lower than undercapitalized banks in the short run, other things remain constant. These findings are similar to the most recent study of Bagntasarian and Mamatzakis (2019). The effect of liquidity ratio, bank size, income diversification, operating efficiency, and loans ratio have economic value to discuss. The findings signify that the availability of liquidity decreases the risk in the short run, other things remain constant, which is similar to the empirical findings of Shim (2013). The coefficient of diversification is positive which indicates that the banks having more than one sources of revenues take a greater risk because the revenue diversification boosts the confidence to take more risk in the short run, ceteris paribus. The impact of loan ratio is positive to influence bank risk in the short run; it indicates that when banks lend more there are more chances of loans losses and non-performing loans. The operating efficiency is found to be insignificant whereas the impact of size is positive to affect bank risk in the short run, other things remain unchanged. 


\subsubsection{The Impact of Common Equity Buffer on Total Risk}

Table 4 shows the results regarding the effect of common equity buffer on bank total risk. The lagged risk is significant and positive as before, which indicates that the last year risk is also contributing to the current risk. The findings show that there is a negative relationship between common equity buffer and bank total risk, which is supporting the suggestions of the regulators. The coefficient indicates that common equity buffer is more significant to decrease the total risk. The negative correlation indicates that a $1 \%$ increase in common equity buffer leads to a decrease of $0.579 \%$ of the total risk in the short run, ceteris paribus. The negative relationship between common equity buffer and risk is supported by Saadaoui (2014); Jokipii and Milne (2008) and Ayuso et al. (2004). The results of pre, during and post-crisis periods are not similar. The coefficient shows that common equity buffer was a significant effect on total risk before the crisis. The results also show that the effect of common equity buffer is not similar for well, adequately, under, significantly under, and critically undercapitalized banks in the USA. The impact is more prominent in the case of significantly undercapitalized banks, a coefficient shows that $1 \%$ increase in common equity buffer leads to a decrease of .676\% of the total risk in the short run, other things remain same. The effect is similar for adequately, undercapitalized and critically undercapitalized banks. The theoretical justification is that common equity buffer is more relevant to absorb losses.

Table-4. The impact of common equity buffer on total risk.

\begin{tabular}{|c|c|c|c|}
\hline VARIABLES & Total Risk & Total Risk & Total Risk \\
\hline \multirow[t]{2}{*}{ Lagged. Risk } & $0.201^{* * * *}$ & $0.208^{* * * *}$ & $0.196^{* * *}$ \\
\hline & -0.022 & -0.0238 & -0.0221 \\
\hline \multirow[t]{2}{*}{ Common Equity Buffer } & $-0.579^{* * * *}$ & $-0.577 * * *$ & $-0.676^{* * * *}$ \\
\hline & -0.0601 & -0.0586 & -0.0745 \\
\hline \multirow[t]{2}{*}{ Well-Capitalized Dummy } & & & $0.390^{* *}$ \\
\hline & & & -0.177 \\
\hline \multirow[t]{2}{*}{ Adequately Capitalized Dummy } & & & -0.238 \\
\hline & & & -0.229 \\
\hline \multirow{2}{*}{ Critically Under-Capitalized dummy } & & & 0.177 \\
\hline & & & -0.203 \\
\hline \multirow[t]{2}{*}{ Under-Capitalized Dummy } & & & 0.145 \\
\hline & & & -0.116 \\
\hline \multirow[t]{2}{*}{ Net Interest Margin } & $0.270^{* * * *}$ & $0.252^{* * * *}$ & $0.274^{* * *}$ \\
\hline & -0.0642 & -0.0632 & -0.065 \\
\hline \multirow[t]{2}{*}{ Liquidity Ratio } & $-0.268 * * *$ & $-0.277 * * *$ & $-0.264 * * *$ \\
\hline & -0.0253 & -0.0249 & -0.0253 \\
\hline \multirow[t]{2}{*}{ Bank Size } & $0.0120^{* * *}$ & 0.00515 & $0.0125 * * *$ \\
\hline & -0.00272 & -0.00332 & -0.00271 \\
\hline \multirow{2}{*}{ Income Diversification } & $0.0401 * * *$ & $0.0439^{* * * *}$ & $0.0411 * * *$ \\
\hline & -0.00896 & -0.00911 & -0.00898 \\
\hline \multirow{2}{*}{ Operating Efficiency } & 0.103 & 0.0887 & 0.109 \\
\hline & -0.0661 & -0.066 & -0.0663 \\
\hline \multirow[t]{2}{*}{ Loan Ratio } & $0.685^{* * * *}$ & $0.685^{* * *}$ & $0.685^{* * *}$ \\
\hline & -0.0182 & -0.018 & -0.0183 \\
\hline \multirow{2}{*}{ Before Crisis Dummy } & & $-0.0761^{* * *}$ & \\
\hline & & -0.0266 & \\
\hline \multirow[t]{2}{*}{ During Crisis Dummy } & & -0.0275 & \\
\hline & & -0.0207 & \\
\hline \multirow[t]{2}{*}{ Constant } & -0.0107 & $0.0788^{*}$ & -0.0143 \\
\hline & -0.0373 & -0.0441 & -0.0376 \\
\hline Observations & 14,130 & 14,130 & 14,130 \\
\hline Number of ids & 942 & 942 & 942 \\
\hline
\end{tabular}




\subsubsection{The Impact of Tier I Capital Buffer on Total risk}

Table 5 shows the results of the impact of tier one capital buffer on the total risk. The coefficient of lagged risk is positive and significant at $1 \%$ level of confidence to influence the current risk. The results indicate that tier one capital buffer is also affecting the total risk negatively in the short run; other factors remain similar. The coefficient shows that a $1 \%$ increase in tier one capital buffer leads to a decrease of $1.157 \%$ of the total risk in the short run. The results also remain similar in before crisis period where the $1 \%$ increase in tier one capital buffer leads to a decrease of $1.2131 \%$ of the total risk in the short run; other things held constant. The tier one capital buffer is more significant than the common equity buffer and capital buffer to influence the total risk. The main reason is that capital buffer includes tier II capital and common equity, and retained earnings are not included. However, the tier one capital includes retain earnings and excludes tier two capital. These findings also reflect the importance of tier one capital buffer. These findings are again supporting the regulators' stance.

Table-5. The impact of Tier I Capital Buffer on Total risk.

\begin{tabular}{|c|c|c|}
\hline VARIABLES & Total Risk & Total Risk \\
\hline \multirow[t]{2}{*}{ Lagged. Risk } & $0.579^{* * * *}$ & $0.587 * * *$ \\
\hline & -0.0284 & -0.0293 \\
\hline \multirow[t]{2}{*}{ Tier I Capital Buffer } & $-1.157 * * *$ & $-1.133^{* * * *}$ \\
\hline & -0.114 & -0.116 \\
\hline \multirow{2}{*}{ Before Crisis Dummy } & & $-0.0801^{* *}$ \\
\hline & & -0.0389 \\
\hline \multirow[t]{2}{*}{ During Crisis Dummy } & & -0.036 \\
\hline & & -0.035 \\
\hline \multirow[t]{2}{*}{ Net Interest Margin } & $0.329 * * *$ & $0.306 * * *$ \\
\hline & -0.1 & -0.1 \\
\hline \multirow[t]{2}{*}{ Liquidity } & $-0.800^{* * *}$ & $-0.816^{* * * *}$ \\
\hline & -0.0384 & -0.0395 \\
\hline \multirow[t]{2}{*}{ Bank Size } & $0.0272^{* * * *}$ & $0.0210^{* * * *}$ \\
\hline & -0.00317 & -0.00425 \\
\hline \multirow[t]{2}{*}{ Income Diversification } & $0.115^{* * *}$ & $0.118^{* * * *}$ \\
\hline & -0.0129 & -0.0136 \\
\hline \multirow[t]{2}{*}{ Operating Efficiency } & $0.215^{*}$ & 0.188 \\
\hline & -0.122 & -0.122 \\
\hline \multirow[t]{2}{*}{ Loan Ratio } & $0.0224^{*}$ & $0.0273^{* *}$ \\
\hline & -0.0118 & -0.0121 \\
\hline \multirow[t]{2}{*}{ Constant } & -0.0324 & 0.0432 \\
\hline & -0.0384 & -0.0514 \\
\hline Observations & 14,085 & 14,085 \\
\hline Number of ids & 939 & 939 \\
\hline
\end{tabular}

\subsubsection{The Impact of Capital Buffer on Net Interest Margin}

Table 6 contains the findings of the effect of bank capital buffer on net interest margin. The results show that there is a positive relationship between a capital buffer and net interest margin in the short run, ceteris paribus, which is similar to the findings of Ayuso et al. (2004); Alfon et al. (2004) and Berger (1995). The one percent increase in capital buffer leads to an increase of $0.024 \%$ of the net interest margin. The findings show that a one percent increase in the capital buffer in the post-crisis period leads to 0.258 percent increase in net interest margin whereas the positive rate of change was $0.2438,0.2292$ during and pre-crisis period, respectively. Shim (2013); Flannery and Rangan (2008); Batten and Vo (2019) and Nier and Baumann (2006) also found a positive relationship between capital buffer and profitability. The results show that the interest margin rate is increasing with the passage of time by implementing conservative capital buffer condition on commercial banks in the short run, other things held constant. These results also indicate that as the banks 
increase their capital buffer, their funds remain unused which leads to a decrease in profits but the expenses remain constant which leads to an increase in the net interest margin as suggested in the mean-variance framework. The subgroups dummies are used to inspect the effect of well capitalized, adequately capitalized undercapitalized, significantly undercapitalized and critically undercapitalized commercial banks. The results show that the influence of capital buffer on the net interest margin is not similar in all subgroups. The influence of critically undercapitalized banks is different to charge net interest margin as compared to other groups in the short run, ceteris paribus. The results show that there is a positive relationship between bank risk and net interest margin. According to the economic theory, the higher the risk is, the higher the return will be, other things remain the same, which is similar to the finding of Batten and Vo (2019). The findings show that the operating efficiency have a positive impact on the net interest margin. The loan ratio and bank size have a negative relationship with net interest margin, which indicates that the needs of granting excessive loans force banks to lower their interest margin in the short run, ceteris paribus.

Table-6. The impact of Capital Buffer on Net Interest Margin.

\begin{tabular}{|c|c|c|c|}
\hline VARIABLES & $\begin{array}{c}\text { Net Interest } \\
\text { Margin }\end{array}$ & $\begin{array}{c}\text { Net Interest } \\
\text { Margin }\end{array}$ & $\begin{array}{c}\text { Net Interest } \\
\text { Margin }\end{array}$ \\
\hline \multirow{2}{*}{ Lagged Net Interest Margin } & $0.441^{* * * *}$ & $0.427 * * *$ & $0.440^{* * *}$ \\
\hline & -0.0407 & -0.0426 & -0.0409 \\
\hline \multirow[t]{2}{*}{ Capital Buffer } & $0.0240^{* * * *}$ & $0.0258^{* * * *}$ & $0.0349^{* *}$ \\
\hline & -0.00853 & -0.00852 & -0.0143 \\
\hline \multirow[t]{2}{*}{ Well Capitalized Dummy } & & & -0.0163 \\
\hline & & & -0.0205 \\
\hline \multirow[t]{2}{*}{ Adequately Capitalized Dummy } & & & -0.025 \\
\hline & & & -0.0282 \\
\hline \multirow[t]{2}{*}{ Under-Capitalized Dummy } & & & -0.00935 \\
\hline & & & -0.0184 \\
\hline \multirow[t]{2}{*}{$\begin{array}{l}\text { Critically Undercapitalized } \\
\text { Dummy }\end{array}$} & & & $-0.101^{*}$ \\
\hline & & & -0.0587 \\
\hline \multirow[t]{2}{*}{ Total Risk } & $0.00994^{* * *} *$ & $0.0103^{* * * *}$ & $0.0100^{* * * *}$ \\
\hline & -0.00209 & -0.00209 & -0.0021 \\
\hline \multirow{2}{*}{ Liquidity Ratio } & 0.00552 & -0.000155 & 0.00524 \\
\hline & -0.00442 & -0.00439 & -0.00444 \\
\hline \multirow[t]{2}{*}{ Bank Size } & $-0.00650^{* * * *}$ & $-0.00842^{* * *} *$ & $-0.00655^{* * * *}$ \\
\hline & -0.000452 & -0.000607 & -0.000451 \\
\hline \multirow[t]{2}{*}{ Operating Efficiency } & $0.264^{* * * *}$ & $0.245^{* * *}$ & $0.263^{* * *}$ \\
\hline & -0.0223 & -0.0225 & -0.0224 \\
\hline \multirow[t]{2}{*}{ Loan Ratio } & $-0.00982^{* * * *}$ & $-0.00797^{* * *} *$ & $-0.00971^{* * * *}$ \\
\hline & -0.0012 & -0.00126 & -0.00121 \\
\hline \multirow[t]{2}{*}{ Before Crisis Dummy } & & $-0.0288^{* * * *}$ & \\
\hline & & -0.00467 & \\
\hline \multirow[t]{2}{*}{ During Crisis Dummy } & & $-0.0142^{* * * *}$ & \\
\hline & & -0.0034 & \\
\hline \multirow[t]{2}{*}{ Constant } & $0.0968^{* * * *}$ & $0.123^{* * *} *$ & $0.0973^{* * * *}$ \\
\hline & -0.00668 & -0.0087 & -0.00667 \\
\hline Observations & 14,085 & 14,085 & 14,085 \\
\hline Number of ids & 939 & 939 & 939 \\
\hline
\end{tabular}

\subsubsection{Impact of Common Equity Buffer on Net Interest Margin}

Table 7 contains the results of the effect of common equity buffer on the net interest margin. The findings show that the relationship between common equity buffer and net interest margin is positive, which indicates that as the common equity buffer of banks increases the bank net interest margin also increases, other things remain similar. The coefficient shows that a $1 \%$ increase in common equity buffer leads to an increase of 
$0.0304 \%$ in net interest margin in the short run, ceteris paribus, which is similar to the findings is Batten and Vo (2019); Berger (1995) and Bagntasarian and Mamatzakis (2019). The results indicate that in the pre-crisis and during the crisis periods the interest margin was lower than in the post-crisis period, which signifies the impact of capital restrictions imposed by regulators in Basel-III. The comparison of banks based on their capitalization generated interesting findings that are worth the attention of the concerned stakeholders. The impact of common equity buffer on the net interest margin is not similar in well, adequately, under, significantly and critically undercapitalized banks. The impact of common equity buffer is negative in the case of critically undercapitalized banks, which indicates that the banks which have a capital problem cannot charge higher interest margin, other things remain constant. The negative association between net interest margin and common equity buffer may be owing to the availability of limited borrowers caused by the lack of confidence resultant from the bank poor condition in the market. The effect of common equity buffer on the total risk is positive and significant in case of well, adequately, and under capital banks.

Table-7. Impact of Common Equity Buffer on Net Interest Margin.

\begin{tabular}{|c|c|c|c|}
\hline VARIABLES & $\begin{array}{c}\text { Net Interest } \\
\text { Margin }\end{array}$ & $\begin{array}{c}\text { Net Interest } \\
\text { Margin }\end{array}$ & $\begin{array}{c}\text { Net Interest } \\
\text { Margin }\end{array}$ \\
\hline \multirow[t]{2}{*}{ Lagged Net Interest Margin } & $0.436 * * *$ & $0.418^{* * *}$ & $0.437 * * *$ \\
\hline & -0.0411 & -0.0433 & -0.0413 \\
\hline \multirow[t]{2}{*}{ Common Equity Buffer } & $0.0304^{* * *}$ & $0.0286^{* * *}$ & $-0.0681^{*}$ \\
\hline & -0.00731 & -0.00715 & -0.0351 \\
\hline \multirow{2}{*}{ Well Capitalized Dummy } & & & $0.105 * * *$ \\
\hline & & & -0.0387 \\
\hline \multirow[t]{2}{*}{ Adequately Capitalized Dummy } & & & $0.0819^{* *}$ \\
\hline & & & -0.0402 \\
\hline \multirow[t]{2}{*}{ Under-Capitalized Dummy } & & & $0.0965^{* * * *}$ \\
\hline & & & -0.0336 \\
\hline \multirow[t]{2}{*}{ Significantly Under-Capitalize Dummy } & & & $0.105 * * *$ \\
\hline & & & -0.0368 \\
\hline \multirow[t]{2}{*}{ Total Risk } & $0.0110^{* * *}$ & $0.0110^{* * * *}$ & $0.0110^{* * * *}$ \\
\hline & -0.00209 & -0.00209 & -0.00208 \\
\hline \multirow[t]{2}{*}{ Liquidity Ratio } & 0.00507 & -0.00135 & 0.00506 \\
\hline & -0.00442 & -0.00437 & -0.00442 \\
\hline \multirow[t]{2}{*}{ Bank Size } & $-0.00657^{*} * *$ & $-0.00873^{* * * *}$ & $-0.00657 * * *$ \\
\hline & -0.000452 & -0.000617 & -0.000451 \\
\hline \multirow[t]{2}{*}{ Operating Efficiency } & $0.262^{* * * *}$ & $0.243^{* * *} *$ & $0.262^{* * * *}$ \\
\hline & -0.0224 & -0.0223 & -0.0224 \\
\hline \multirow[t]{2}{*}{ Loan Ratio } & $-0.00964 * * *$ & $-0.00759^{* * * *}$ & $-0.00966^{* * *}$ \\
\hline & -0.00118 & -0.00125 & -0.00119 \\
\hline \multirow[t]{2}{*}{ Before Crisis Dummy } & & $-0.0232^{* * * *}$ & \\
\hline & & -0.00343 & \\
\hline \multirow[t]{2}{*}{ During Crisis Dummy } & & $-0.0114^{* * * *}$ & \\
\hline & & -0.00247 & \\
\hline \multirow[t]{2}{*}{ Constant } & $0.0961 * * *$ & $0.126 * * *$ & $0.0959^{* * * *}$ \\
\hline & -0.0067 & -0.00892 & -0.00671 \\
\hline Observations & 14,085 & 14,085 & 14,085 \\
\hline Number of ids & 939 & 939 & 939 \\
\hline
\end{tabular}

4.3.6. Impact of Tier I Capital Buffer on Net Interest Margin

Table 8 provides the results of the effect of tier one capital buffer on the net interest margin in pre, during and post-crisis period of well, adequately, under, significantly under, and critically undercapitalized commercial bank. The findings conclude that tier one capital has a positive impact on the net interest margin, which indicates that by increasing capital buffer, the profitability decreases (Batten and Vo, 2019). The banks want to 
earn their target profits by making limited loans for which they charge a higher interest margin. The results indicate that in the pre-crisis period, the interest rate was lower than the post-crisis. Similar findings remain during the crisis, which means the net interest margin was lower as compared to the post-crisis period. The results for well, adequately, under, significantly under and critically undercapitalized banks indicate that they behave similarly to set their interest margin. The reason for charging of higher interest margin may be the greater demand and lower availability of funds to lend. these findings are similar to Batten and Vo (2019); Bagntasarian and Mamatzakis (2019) and Berger (1995). These findings provide evidence supporting the regulators' recommendations.

Table-8. Impact of Tier I Capital Buffer on Net Interest Margin.

\begin{tabular}{|c|c|c|}
\hline VARIABLES & Net Interest Margin & Net Interest Margin \\
\hline \multirow[t]{2}{*}{ Lagged Net Interest Margin } & $0.446^{* * * *}$ & $0.430^{* * *} *$ \\
\hline & -0.0406 & -0.0427 \\
\hline \multirow{2}{*}{ Tier I Capital Buffer } & $0.0176^{*}$ & $0.0178^{*}$ \\
\hline & -0.00912 & -0.00911 \\
\hline \multirow[t]{2}{*}{ Before Crisis Dummy } & & $-0.0274^{*} * *$ \\
\hline & & -0.00427 \\
\hline \multirow[t]{2}{*}{ During Crisis Dummy } & & $-0.0141 * * *$ \\
\hline & & -0.0031 \\
\hline \multirow[t]{2}{*}{ Total Risk } & $0.00925^{* * *} *$ & $0.00967 * * *$ \\
\hline & -0.00207 & -0.00207 \\
\hline \multirow[t]{2}{*}{ Liquidity Ratio } & 0.00599 & $-6.97 \mathrm{E}-05$ \\
\hline & -0.00444 & -0.00439 \\
\hline \multirow[t]{2}{*}{ Bank Size } & $-0.00642^{* * *} *$ & $-0.00849 * * *$ \\
\hline & -0.00045 & -0.000617 \\
\hline \multirow[t]{2}{*}{ Operating Efficiency } & $0.265^{* * *} *$ & $0.245^{* * * *}$ \\
\hline & -0.0224 & -0.0225 \\
\hline \multirow[t]{2}{*}{ Loan Ratio } & $-0.0102^{* * *} *$ & $-0.00816^{* * *}$ \\
\hline & -0.00119 & -0.00126 \\
\hline \multirow[t]{2}{*}{ Constant } & $0.0965^{* * * *}$ & $0.125^{* * *} *$ \\
\hline & -0.00665 & -0.00884 \\
\hline Observations & 14,085 & 14,085 \\
\hline Number of ids & 939 & 939 \\
\hline
\end{tabular}

\section{CONCLUSION}

The findings show that capital buffer, common equity buffer, tier one capital buffer and total risk are negatively correlated, which is supporting the recommendations of the Basel-III regulators. In Basel-III, banks are recommended to increase their capital in order to increase their loss absorption capacity. However, the impact of tier one capital buffer is more significant to reduce risk as compared to capital buffer and common equity buffer. The findings are aligned with the economic theory because in real sense tier capital has the ability to absorb maximum losses. The tier one capital includes the common equity and retained earnings, and capital buffer includes tier two capital, which has no loss absorption features. The most important is lagged risk, which has a positive effect on the current risk. It indicates that bank managers must consider the previous risk for future decision-making. The findings of period dummies show that capital buffer is influencing the total risk differently in pre, during and post-crisis. The results of dummies conclude that the effect of capital buffer on risk is not similar for well, adequately, under, significantly under and critically undercapitalized banks.

The results also show that capital buffer, common equity buffer and tier one capital buffer have a positive effect on the net interest margin. The results indicate that in pre-crisis and during the crisis period, the interest margin was lower than the post-crisis period, which signifies the impact of capital restrictions imposed by 
regulators in Basel-III. The results show that the interest margin rate is increasing with the passage of time by implementing conservative capital buffer condition on commercial banks in the short run, other things held constant. These results also reflect that as the banks increase their capital buffer, their funds remain unused, which leads to a decrease in profits. However, the expenses remain constant, which leads to an increase in the net interest margin as suggested in the mean-variance framework. The subgroups dummies are used to inspect the effect of well, adequately, under, significantly under and critically undercapitalized commercial banks. The results show that the influence of capital buffer on the net interest margin is not similar in all subgroups. The influence of critically undercapitalized banks is different to charge net interest margin as compared to other groups in the short run, ceteris paribus. The results show that there is a positive relationship between bank risk and the net interest margin. According to the economic theory, the higher the risk is, the higher the return will be, other things remain. The findings show that the relationship between common equity buffer and net interest margin is positive, which indicates that as the common equity buffer of banks increases, the bank net interest margin also increases, other things remain similar. The impact of common equity buffer is negative in the case of critically undercapitalized banks, which indicates that the banks which have a capital problem cannot charge higher interest margin, other things remain constant. In other words, the negative association between net interest margin and common equity buffer may be owing to the availability of limited borrowers caused by lack of confidence lead by the bank poor condition in the market. The effect of common equity buffer on the total risk is positive and significant in case of well, adequately, and under capital banks. The findings show that tier one capital has a positive impact on net interest margin, which indicates that by increasing capital buffer, the profitability decrease. The banks want to earn their target profits by making limited loans for which they charge higher interest margin. The findings provide valuable information for decision makers, regulators and bankers.

\section{REFERENCES}

Aggarwal, R. and K.T. Jacques, 2001. The impact of FDICIA and prompt corrective action on bank capital and risk: Estimates using a simultaneous equations model. Journal of Banking \& Finance, 25(6): 1139-1160.Available at: https://doi.org/10.1016/s0378-4266(00)00125-4.

Alfon, I., I. Argimon and P. Bascuñana-Ambrós, 2004. What determines how much capital is held by UK banks and building societies? London: Financial Services Authority.

Altunbas, Y., S. Carbo, E.P. Gardener and P. Molyneux, 2007. Examining the relationships between capital, risk and efficiency in European banking. European Financial Management, 13(1): 49-70.Available at: https://doi.org/10.1111/j.1468036x.2006.00285.x.

Arellano, M. and O. Bover, 1995. Another look at the instrumental variable estimation of error-components models. Journal of Econometrics, 68(1): 29-51.Available at: https://doi.org/10.1016/0304-4076(94)01642-d.

Ayuso, J., D. Pérez and J. Saurina, 2004. Are capital buffers pro-cyclical? Evidence from Spanish panel data. Journal of Financial Intermediation, 13(2): 249-264.Available at: https://doi.org/10.1016/s1042-9573(03)00044-5.

Bagntasarian, A. and E. Mamatzakis, 2019. Testing for the underlying dynamics of bank capital buffer and performance nexus. Review of Quantitative Finance and Accounting, 52(2): 347-380.Available at: https://doi.org/10.1007/s11156-018$0712-y$.

Batten, J. and X.V. Vo, 2019. Determinants of bank profitability-Evidence from Vietnam. Emerging Markets Finance and Trade, 55(6): 1417-1428.

Berger, A.N., 1995. The relationship between capital and earnings in banking. Journal of Money, Credit and Banking, 27(2): 432456.Available at: https://doi.org/10.2307/2077877. 
Bitar, M., K. Pukthuanthong and T. Walker, 2018. The effect of capital ratios on the risk, efficiency and profitability of banks: Evidence from OECD countries. Journal of International Financial Markets, Institutions and Money, 53(C): 227262.Available at: https://doi.org/10.1016/j.intfin.2017.12.002.

Blundell, R. and S. Bond, 2000. GMM estimation with persistent panel data: An application to production functions. Econometric Reviews, 19(3): 321-340.Available at: https://doi.org/10.1080/07474930008800475.

Buser, S.A., A.H. Chen and E.J. Kane, 1981. Federal deposit insurance, regulatory policy, and optimal bank capital. The Journal of Finance, 36(1): 51-60.Available at: https://doi.org/10.1111/j.1540-6261.1981.tb03534.x.

Casu, B. and C. Girardone, 2006. Bank competition, concentration and efficiency in the single European market. The Manchester School, 74(4): 441-468.Available at: https://doi.org/10.1111/j.1467-9957.2006.00503.x.

Flannery, M.J. and K.P. Rangan, 2008. What caused the bank capital build-up of the 1990s? Review of Finance, 12(2): 391429.Available at: https://doi.org/10.1093/rof/rfmoo7.

Guidara, A., I. Soumaré and F.T. Tchana, 2013. Banks' capital buffer, risk and performance in the Canadian banking system: Impact of business cycles and regulatory changes. Journal of Banking \& Finance, 37(9): 3373-3387.Available at: https://doi.org/10.1016/j.jbankfin.2013.05.012.

Guidaraa, A., V. Lai and I. Soumaré, 2010. Performance, risk, and capital buffer under business cycles and banking regulations: Evidence from the Canadian banking sector: Mimeo: Financial Engineering Laboratory, Laval University.

Jacques, K. and P. Nigro, 1997. Risk-based capital, portfolio risk, and bank capital: A simultaneous equations approach. Journal of Economics and Business, 49(6): 533-547.Available at: https://doi.org/10.1016/s0148-6195(97)00038-6.

Jensen, M.C. and W.H. Meckling, 1976. Theory of the firm: Managerial behavior, agency costs and ownership structure. Journal of Financial Economics, 3(4): 305-360.Available at: https://doi.org/10.1016/0304-405x(76)90026-x.

Jokipii, T. and A. Milne, 2008. The cyclical behaviour of European bank capital buffers. Journal of Banking \& Finance, 32(8): 1440-1451.Available at: https://doi.org/10.1016/j.jbankfin.2007.12.001.

Jokipii, T. and A. Milne, 2011. Bank capital buffer and risk adjustment decisions. Journal of Financial Stability, 7(3): 165178.Available at: https://doi.org/10.1016/j.jfs.2010.02.002.

Krug, S., M. Lengnick and H.W. Wohltmann, 2015. The impact of Basel III on financial (in) stability: An agent-based credit network approach. Quantitative Finance, 15(12): 1917-1932.Available at: https://doi.org/10.1080/14697688.2014.999701.

Lee, C.-C. and M.-F. Hsieh, 2013. The impact of bank capital on profitability and risk in Asian banking. Journal of International Money and Finance, 32(C): 251-281.Available at: https://doi.org/10.1016/j.jimonfin.2012.04.013.

Molyneux, P., 2018. Developments in banking research and areas for future study. International Journal of the Economics of Business, 25(1): 167-179.Available at: https://doi.org/10.1080/13571516.2017.1399654.

Mongid, A., I.M. Tahir and S. Haron, 2012. The relationship between inefficiency, risk and capital evidence from commercial banks in ASEAN (Doctoral Dissertation, Universiti Putra Malaysia).

Myers, S.C., 1984. The capital structure puzzle. The Journal of Finance, 39(3): 574-592.Available at: https://doi.org/10.1111/j.1540-6261.1984.tb03646.x.

Nier, E. and U. Baumann, 2006. Market discipline, disclosure and moral Hazard in banking. Journal of Financial Intermediation, 15(3): 332-361.Available at: https://doi.org/10.1016/j.jfi.2006.03.001.

Rime, B., 2001. Capital requirements and bank behaviour: Empirical evidence for Switzerland. Journal of Banking \& Finance, 25(4): 789-805.Available at: https://doi.org/10.1016/s0378-4266(00)00105-9.

Robin, I., R. Salim and H. Bloch, 2018. Financial performance of commercial banks in the post-reform era: Further evidence from Bangladesh. Economic Analysis and Policy, 58(C): 43-54.Available at: https://doi.org/10.1016/j.eap.2018.01.001.

Saadaoui, Z., 2014. Business cycle, market power and bank behaviour in emerging countries. International Economics, 139: 109132.Available at: https://doi.org/10.1016/j.inteco.2014.04.001. 
Shim, J., 2013. Bank capital buffer and portfolio risk: The influence of business cycle and revenue diversification. Journal of Banking \& Finance, 37(3): 761-772.Available at: https://doi.org/10.1016/j.jbankfin.2012.10.002.

Shrieves, R.E. and D. Dahl, 1992. The relationship between risk and capital in commercial banks. Journal of Banking \& Finance, 16(2): 439-457.Available at: https://doi.org/10.1016/0378-4266(92)90024-t.

Tabak, B., D. Li, J. Vasconcelos and D. Cajueiro, 2013. Do capital buffers matter? A study on the profitability and funding costs determinants of the Brazilian banking system (No. 333). Central Bank of Brazil, Research Department.

Thakor, A.V., 2018. Post-crisis regulatory reform in banking: Address insolvency risk, not illiquidity! Journal of Financial Stability, 37(C): 107-111.Available at: https://doi.org/10.1016/j.jfs.2018.03.009.

Windmeijer, F., 2005. A finite sample correction for the variance of linear efficient two-step GMM estimators. Journal of Econometrics, 126(1): 25-51.Available at: https://doi.org/10.1016/j.jeconom.2004.02.005.

Online Science Publishing is not responsible or answerable for any loss, damage or liability, etc. caused in relation to/arising out of the use of the content. Any queries should be directed to the corresponding author of the article. 